\title{
HUNIAN WARGA YANG 'KOMPAK DAN BERKELANJUTAN' DI KAMPUNG SAWAH, JAKARTA UTARA
}

\author{
Erika Visca Lina ${ }^{1)}$
}

${ }^{1)}$ Program Studi S1 Arsitektur, Fakultas Teknik, Universitas Tarumanagara, erika.visca@gmail.com

\begin{abstract}
Abstrak
Perkembangan kota ditandai dengan urban sprawl, karena terbatasnya lahan tinggal menyebabkan pembangunan hunian di pinggir kota. Fragmentasi lahan akibat urban sprawl mengakibatkan diperlukannya mobilitas tinggi. Dengan karakteristik permukiman di daerah urban sprawl yang menggunakan lahan besar dan luasan rumah yang besar juga membuat kebutuhan air dan energi terutama listrik meningkat. Karena kurangnya penataan dan regulasi yang jelas dari pemerintah pusat, penduduk yang menolak tinggal jauh dari tempat bekerja memilih untuk tinggal di area kampung kota. Akibat kekurangan lahan permukiman, mulai bermunculan permukiman tidak layak di area perkotaan, yang sering disebut kampung kota. Meskipun letaknya di perkotaan, kampung kota masih bersifat kampung yang sulit diakses, masalah kemiskinan penduduk, dan merupakan adaptasi penduduk akan kurangnya lahan tinggal. Kampung Kota yang terbentuk secara organik merupakan cermin kebutuhan vital penduduk kota, yakni aksesibilitas dan lingkungan hidup yang nyaman. Solusi untuk permasalahan urban sprawl dapat diatasi dengan prinsip compact city, yang telah tercermin dalam Kampung Kota. Compact city adalah sebuah perencanaan urban yang berfokus pada fungsi mixed-use padat penduduk. Konsep ini memiliki dasaran penggunaan transportasi publik yang efisien dan memiliki tatanan urban yang mendorong penduduknya untuk berjalan kaki atau bersepeda, konsumsi energi yang rendah, dan mengurangi polusi. Oleh karena itu perluasan kampung kota dengan prinsip compact city yang similar satu sama lain dapat diterapkan. Prinsip compact city yang telah tercermin dalam kampung kota di Kampung Sawah diharapkan dapat menjadi prototype hunian kompak kampung kota.
\end{abstract}

\section{Kata kunci: compact city; kampung kota; kampung sawah; urban sprawl}

\begin{abstract}
Urban sprawl due to limited land for living causes more residential development on the edge of the city. Land fragmentation results in the need for high mobility. With the characteristics of settlements in urban sprawl areas that use large land and large house areas, the demand for water and energy, especially electricity, increases. Due to the lack of clear arrangements and regulations from the central government, residents who refuse to live far from their place of work choose to live in the urban village area. Due to the shortage of residential land, inadequate settlements began to appear in urban areas, which are often called Kampung Kota. Even though it is located in an urban area, Kampung Kota is still a village with difficult access, poor population, and is a form of adaptation to the lack of residential land. The organically formed Kampung Kota is a reflection of the vital needs of the city dwellers, namely accessibility and a comfortable living environment. The solution to the problem of urban sprawl can be overcome with the compact city principle, which has been reflected in Kampung Kota which was originally organic. Compact city is an urban planning that focuses on densely populated mixed-use functions. This concept is based on the use of efficient public transportation and has an urban setting that encourages residents to walk or cycle, lower energy consumption, and reduce pollution. Therefore, the expansion of Kampung Kota with compact city principles that are similar to each other can be applied also is expected to become a prototype for compact Kampung Kota housing.
\end{abstract}

Keywords: compact city; kampung sawah; urban sprawl; urban village 


\section{PENDAHULUAN}

\section{Latar Belakang}

Kini Indonesia berada di kategori menengah urbanisasi. Bank Dunia mencatat, populasi urbanisasi Indonesia pada 2017 hampir mencapai 55\%. Seperti di negara-negara lainnya, urbanisasi di Indonesia dipicu utama oleh faktor ekonomi, terutama di sektor industri dan jasa. Diprediksi 220 juta penduduk Indonesia akan tinggal di kota-kota besar dan kecil pada tahun 2045 , naik hingga $70 \%$ dari total populasi secara keseluruhan. Besarnya angka tersebut tidak diiringi dengan pembangunan fasilitas yang memadai. Hingga saat ini belum seluruh masyarakat perkotaan dapat mengakses layanan dasar dan infrastruktur dasar perkotaan yang tersedia. Padahal, penduduk yang bekerja sangat membutuhkan akses transportasi untuk berpindah dari tempat tinggal ke tempat bekerja.

Secara fisik, perkembangan kota ditandai dengan urban sprawl. Urban Sprawl adalah fenomena pemekaran kota ke daerah-daerah di sekitarnya secara acak tanpa adanya rencana. Efek samping yang dipicu antara lain konversi tanah pertanian dan lahan resapan air, inefisiensi pembangunan sarana dan prasarana, meningkatkan arus lalu lintas, polusi dan penggunaan energi yang besar. Ruang terbuka hijau dan ruang publik semakin terbatas bagi penduduk, hingga persediaan hunian. Di Indonesia, diperkirakan terdapat sekitar 57.800 hektar perumahan yang dikategorikan tidak layak huni dan memerlukan perhatian dan perbaikan. Sementara itu, 20,5 juta penduduk miskin kota menempati rumah tidak layak huni (Kementrian Perumahan Rakyat, 2010). Akibat kekurangan lahan permukiman, mulai bermunculan permukiman tidak layak di area perkotaan, yang sering disebut kampung kota. Meskipun letaknya di perkotaan, kampung kota masih bersifat kampung yang sulit diakses, kemiskinan penduduk, dan merupakan adaptasi penduduk akan kurangnya lahan tinggal. Kampung kota yang terbentuk secara organik merupakan cermin kebutuhan vital penduduk kota, yakni aksesibilitas dan lingkungan hidup yang nyaman. Oleh karena itu, kebutuhan lahan permukiman, penggunaan energi untuk transportasi, fasilitas lingkungan yang belum tersebar rata untuk mendukung kehidupan menjadi fokus utama yang dapat diselesaikan oleh eksistensi kampung kota, jika diolah dengan baik.

\section{Rumusan Permasalahan}

Dari permasalahan urban sprawl tersebut maka perlu diketahui mengenai cara membentuk Kawasan kampung kota yang berintegrasi dengan prinsip compact city. Hal ini diwujudkan melalui penerapan program yang tepat demi menciptakan lingkungan tinggal yang aksesibel bagi penduduk kampung, serta low cost maintenance.

\section{Tujuan}

Proyek ini bertujuan untuk menciptakan program yang tepat guna bagi penduduk sekitar, mengurangi dampak buruk akibat urban sprawl terutama di daerah DKI Jakarta terutama mengurangi emisi karbon dan dampak negatif lain akibat kebutuhan mobilitas yang tinggi. Hal ini diwujudkan melalui penerapan prinsip compact city dan konsep sustainable atau arsitektur berkelanjutan, yang kemudian diharapkan mampu menciptakan lingkungan tinggal zero energy based untuk mengurangi maintenance akibat urban sprawl.

\section{KAJIAN LITERATUR}

\section{Arsitektur yang Ekologis}

Arsitektur berkelanjutan yang ekologis dapat dikenali dengan cara seperti tidak menghabiskan bahan lebih cepat daripada tumbuhnya kembali bahan tersebut oleh alam; menggunakan energi terbarukan secara optimal; menghasilkan sampah yang dapat dimanfaatkan sebagai sumber bahan baru. Arsitektur ekologis merncerminkan adanya perhatian terhadap lingkungan alam dan sumber alam yang terbatas. Secara umum, arsitektur ekologis dapat diartikan 
sebagai penciptaan lingkungan yang lebih sedikit mengkonsumsi dan lebih banyak menghasilkan kekayaan alam. Arsitektur tidak dapat mengelak dari tindakan perusakan lingkungan. Namun demikian, arsitektur ekologis dapat digambarkan sebagai arsitektur yang hendak merusak lingkungan sesedikit mungkin. Untuk mencapai kondisi tersebut, desain diolah dengan cara memperhatikan aspek iklim, rantai bahan, dan masa pakai material bangunan. Prinsip utama arsitektur ekologis adalah menghasilkan keselarasan antara manusia dengan lingkungan alamnya.

\section{Urbanisasi dan Pengkotaan di Indonesia}

Urbanisasi secara harfiah adalah proses pengkotaan suatu wilayah. Menurut Prof. Bintarto (1986), urbanisasi merupakan perpindahan penduduk dari desa ke kota karena kebutuhan kehidupan. Seperti di negara-negara lainnya, urbanisasi di Indonesia dipicu utama oleh faktor ekonomi, terutama di sektor industri dan jasa. Bank Dunia memproyeksi sebanyak 220 juta penduduk Indonesia akan tinggal di kota-kota besar dan kecil pada tahun 2045. Tingkat urbanisasi Indonesia pada tahun 2019 tercatat setara dengan 56\%, pada tahun 2045 diproyeksikan naik hingga 70\% dari total populasi secara keseluruhan.

Menurut data World Bank, antara tahun 2000 hingga 2010, lahan perkotaan di Indonesia meningkat dari sekitar $8.900 \mathrm{~km}^{2}$ menjadi $10.000 \mathrm{~km}^{2}$, bertambah $1.1 \%$ per tahun - laju pertumbuhan lahan perkotaan tertinggi setelah Tiongkok. Pertumbuhan ekonomi yang terjadi di perkotaan mendorong kemajuan negara karena bertambahnya pekerjaan formal dan meningkatkan produktivitas. Namun, pertumbuhan ini tidak maksimal di Indonesia. Indonesia memperoleh hanya $4 \%$ pertumbuhan PDB untuk setiap $1 \%$ pertumbuhan urbanisasi.

Selain karena infrastruktur yang kurang memadai, laju urbanisasi Indonesia juga terhambat karena kepadatan penduduk yang tidak terkontrol. Kepadatan penduduk Indonesia naik pesat dari 7.400 orang per $\mathrm{km}^{2}$ menjadi 9.400 orang per $\mathrm{km}^{2}$. Menurut perkiraan Kementrian Pekerjaan Umum dan Perumahan Rakyat, angka backlog perumahan di Indonesia mencapai sekitar 13.5 juta unit pada tahun 2016. Semakin tinggi laju urbanisasi, kebutuhan akan tempat tinggal juga semakin meningkat. Contohnya adalah kota Jakarta dengan luas wilayah $662.33 \mathrm{~km}^{2}$ memiliki beban tamping yang ideal sekitar 6.5 juta jiwa, namun kondisi eksistingnya jumlah warga Jakarta sudah melebihi angka 13 juta jiwa, mencakup penduduk asal Jakarta dan penduduk migran dari luar Jakarta.

Permasalahan ketersediaan lahan yang tidak memadai dan laju urbanisasi yang terus meningkat membuat pembangunan permukiman di kota menyebar hingga ke daerah pinggiran. Karena kurangnya penataan dan regulasi yang jelas dari pemerintah pusat, maka perkembangan kotakota pinggiran ini kebanyakan dikelola oleh swasta. Karena pusat ekonomi dan bisnis tetap berada di pusat kota, maka lapangan pekerjaan pun tetap bertebaran di pusat kota, sedangkan keterbatasan tempat tinggal di pusat kota membuat pendatang atau migran memilih untuk tinggal di pinggiran kota dan melakukan kegiatan pulang-pergi ke luar daerah kota. Semakin menyebarnya permukiman di sekitar kota, terjadi fenomena yang disebut urban sprawl (Frick, 2007: 1)

\section{Urban Sprawl}

Urban Sprawl adalah fenomena pemekaran kota ke daerah-daerah di sekitarnya secara acak tanpa adanya rencana. Menurut Newman dan Kenworthy (1989) urban sprawl merupakan bentuk dasar terbangunnya kota yang semakin hari mendapat kritikan dikarenakan berbagai segi negative kota yang ditimbulkan. Fenomena ini ditandai dengan adanya ali fungsi lahan di 
sekitar kota (urban periphery) yang menjalar. Urban Sprawl adalah pengembangan yang terjadi di luar pusat kota, biasanya pada lahan yang belum diolah.

\section{Karakteristik Urban Sprawl}

Urban Spraw/ memiliki beberapa ciri dan karakteristik yang terlihat secara fisik maupun secara gaya hidup penduduknya, seperti kepadatan rendah, penggunaan lahan yang besar, jaringan jalan menjalar, kebergantungan terhadap kendaraan bermotor, jarak yang jauh antar sektor (perumahan-komersial-kantor), dan batas antar residensial yang jelas.

\section{Urban Sprawl di Indonesia}

Urban sprawl mengakibatkan dampak positif dan negatif terhadap sebuah Kawasan.

\section{Dampak Positif}

Dampak positif yang terjadi seperti berkembangnya ekonomi lokal; berkembangnya tempat tinggal juga menyebabkan berkembangnya fasilitas di dalamnya. Untuk mempertahankan kehidupan penduduk, ekonomi lokal menciptakan lapangan kerja baru yang juga membantu pertumbuhan ekonomi negara secara keseluruhan; kualitas hidup meningkat; tidak dapat dipungkiri bahwa kehidupan di pinggiran kota lebih nyaman karena pengembangan yang lebih modern dan memang berfokus pada tingkat kenyamanan penduduknya.

\section{Dampak Negatif}

Dampak negative yang terjadi seperti ketergantungan terhadap kendaraan bermotor (Karakteristik urban sprawl adalah memiliki jarak yang jauh antar rumah-pertokoan-perkantoran sehingga tidak efektif untuk pejalan kaki karena jarak yang tergolong jauh, maka kebergantungan penduduk terhadap kendaraan bermotor meningkat); tingkat kemacetan meningkat (Karena banyaknya komuter yang pulang-pergi dari kota ke tempat tinggalnya di daerah pinggiran, penggunaan kendaraan bermotor pun meningkat, sehingga menyebabkan jumlah kendaraan yang tidak sebanding dengan infrastruktur jalanan, yang menyebabkan kemacetan); polusi udara meningkat (karena meningkatnya penggunaan kendaraan bermotor, kemacetan, dan mobilitas tinggi, tingkat polusi udara di perkotaan dan daerah sekitarnya semakin tinggi); polusi air meningkat (pembangunan perumahan pada lahan besar membuat penggunaan air juga meningkat, limbah sampah dan limbah kimia yang dibuang ke air pun meningkat, menyebabkan polusi air); lahan agrikultur dan habitat ekosistem hilang (pembangunan urban sprawl mengambil tanah pinggiran kota yang awalnya adalah hutan, sawah atau lahan bebas menyebabkan hilangnya lahan agrikultur maupun habitat para hewan yang tinggal disitu); kebutuhan air dan energi meningkat (dengan karakteristik permukiman di daerah urban sprawl yang menggunakan lahan besar dan luasan rumah yang besar juga membuat kebutuhan akan air dan energi -terutama listrik- meningkat); efisiensi mobilitas berkurang (jarak tempuh yang jauh mengakibatkan waktu tempuh yang jauh juga, membuat waktu produktivitas berkurang dan tidak efisien)

\section{Kampung Kota}

Definisi kampung /kam·pung/ menurut KBBI ialah kelompok rumah yang merupakan bagian kota (biasanya dihuni orang berpenghasilan rendah); kesatuan administrasi terkecil yang menempati wilayah tertentu, terletak di bawah kecamatan; terkebelakang (belum modern); berkaitan dengan kebiasaan di kampung; kolot. Kampung kota di Indonesia, terutama di Kawasan DKI Jakarta tersebar di berbagai sudut. Terlihat pada peta persebaran kampung di DKI Jakarta, letak kampung kota banyak yang dikelilingi kawasan ramai kegiatan/pusat bisnis. Meskipun demikian, keadaan ekonomi dan penduduk di dalamnya masih terbatas oleh akses dan fasilitas yang tidak mumpuni jika dibandingkan dengan kawasan kota di sekitarnya. Padahal, kampung kota merupakan area yang strategis karena letaknya yang tidak jauh dari pusat kegiatan, serta dapat 
dikembangkan sektor ekonominya sehingga bertimbal balik dengan kota sekitar dan penduduk di dalamnya.

\section{Kampung Kota dan Compact City}

Menurut karakteristik kampung kota di DKI Jakarta, terdapat beberapa prinsip yang sesuai dengan prinsip compact city. Compact city sebagai solusi permasalahan urban sprawl telah tertanam dalam pembangunan kampung kota yang mulanya bersifat organik. Oleh karena itu, perluasan kampung kota dengan prinsip compact city yang similar satu sama lain dapat diterapkan. Fenomena urban sprawl memang sudah terjadi, dan dampak utamanya untuk masalah lingkungan semakin terlihat. Salah satu solusi yang dapat dilakukan adalah pembentukkan sebuah compact city.

\section{Karakteristik Compact City}

Kata compact city pertama kali disebutkan pada tahun 1973 oleh George Dantzig dan Thomas L. Saaty, dua ahli matematikan yang memiliki visi utopia yang banyak di dasarkan oleh pemikiran penggunaan sumber daya yang efisien. Compact city atau sering disebut "city with short distances" adalah sebuah perencanaan urban atau konsep desain urban, yang berfokus pada fungsi mixed-use padat penduduk. Konsep ini memiliki dasaran penggunaan transportasi publik yang efisien dan memiliki tatanan urban yang mendorong penduduknya untuk berjalanan kaki atau bersepeda, konsumsi energy yang rendah, dan mengurangi polusi. Compact city diyakini menjadi solusi yang lebih berkelanjutan dibandingkan urban sprawl karena sifatnya yang lebih tidak bergantung pada kendaraan bermotor, juga kebutuhan infrastruktur yang lebih kecil dan murah per kapita karena kepadatannya (Budiharjo, 1992). Compact city memiliki ciri dan karakteristik yang berbeda dan hampir 180 derajat berkebalikan dengan urban sprawl seperti kepadatan penduduk tinggi, kebergantungan rendah terhadap kendaraan bermotor, fungsi mixed-use, sistem dan jaringan transportasi umum yang efisien, ruang terbuka yang lebih sedikit, jaringan konektivitas jalan tinggi diutamakan untuk jalur pedestrian dan jalur sepeda, dan jarak antar fungsi yang berdekatan (jarak walking distance).

\section{Hunian Kampung Kota yang Compact \& Sustainable}

Kampung dan kota saling bergantung. Perbedaan fisik, administrasi, ketimpangan sosial dan gaya hidup meskipun letaknya yang berdekatan justru saling melengkapi. Dengan prinsip compact city jika dinding pemisah tersebut dilunturkan dapat memperkuat eksistensi kampung, tanpa mengesampingkan karakteristik penduduk kampung. Kebutuhan mobilitas penduduk untuk berpindah dari tempat tinggal ke tempat bekerja sangat perlu diperhatikan demi mengontrol penggunaan energi akibat permasalahan urban sprawl. Oleh karena itu hunian hemat energi yang dipadukan dengan prinsip compact city dapat menjadi solusi dan minimalisir efek samping dari urban sprawl.

\section{METODE}

\section{Lokalitas Penduduk}

Kegiatan berhuni yang komunal, didasarkan oleh kebiasaan penduduk kampung kota yang berbasis komuniti. Karena terbatasnya ruang terbuka hijau, penduduk kampung kota memanfaatkan ruang publik menjadi fungsi hybrid berkumpul dan berkegiatan formal seperti musyawarah. Terbentuknya ruang multifungsi sebagai komersil bersifat publik merupakan bentuk adaptasi penduduk kampung yang dimunculkan dalam rancangan kampung kota yang compact. 


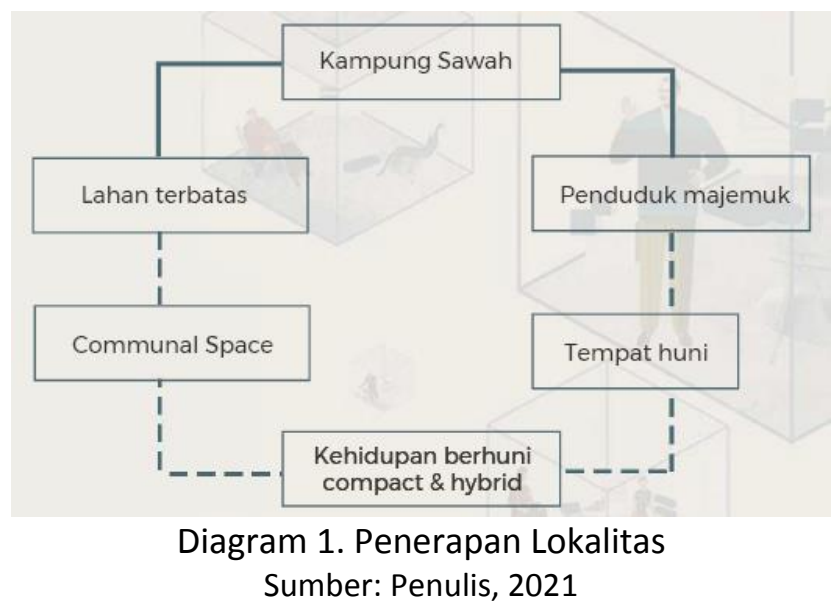

\section{Program Aktivitas}

Program aktivitas yang didasari oleh kebutuhan akan ruang kegiatan dan aktivitas yang mendukung/menunjang untuk membentuk program dalam arsitektur, dalam hal ini adalah program berhuni. Akibat urban sprawl kebutuhan berhuni di lahan fragmentasi perkotaan menjadi lebih tinggi, karena ketergantungan terhadap transportasi yang tinggi. Oleh karena itu munculnya kampung kota merupakan jawaban kebutuhan hunian yang lebih dekat dengan tempat kerja. Kekurangan eksistensi kampung kota yang masih belum didukung fasilitas dan akses memadai, serta kondisi ekonomi yang masih bergantung pada kota di sekitarnya perlu diatasi dengan menyesuaikan kebutuhan akan ruang kegiatan dan aktivitas berhuni di kampung kota.

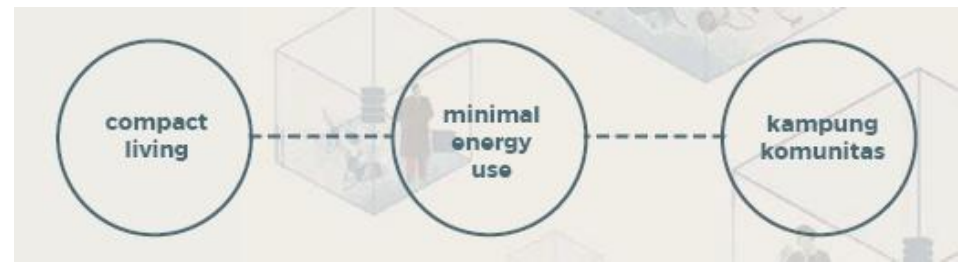

Diagram 2. Program Aktivitas

Sumber: Penulis, 2021

Compact living diwujudkan dengan perancangan bangunan hemat energi serta basis komunitas kampung kota. Program ruang bangunan terbagi menjadi 3 fungsi yang dibagi berdasarkan kegiatan di dalamnya, yaitu unit hunian, fasilitas pendukung hunian, dan area pengolahan energy. Ketiga fungsi tersebut dipadukan dengan fungsi komersil dan komunal atau prinsip kampung komunitas.

\section{DISKUSI DAN HASIL}

\section{Kontekstual Tapak}

Tapak terletak di Jalan Cakung Drainase, Kampung Sawah, Kelurahan Semper Timur, Kecamatan Cilincing, Jakarta Utara. Lahan sebesar $14.800 \mathrm{~m} 2$ ini berada di tepi sungai/kali RW Malang dan berada di zona perkantoran, dagang dan jasa dengan KDB 40\% dan KB 4 lantai. Kampung Sawah dikelilingi oleh pabrik industrial karena kawasan ini merupakan kawasan industri pabrik, dan berbatasan dengan kawasan Marunda yang juga merupakan area industri. Terdapat 1.361 bangunan rumah milik sendiri dan 926 kontrakan. Berdasarkan hal ini, sekitar $40 \%$ keluarga masih tinggal di kontrakan. Bangunan rumah tersebut merupakan rumah permanen yang sudah berupa beton (BPS Jakarta Utara, 2019). 


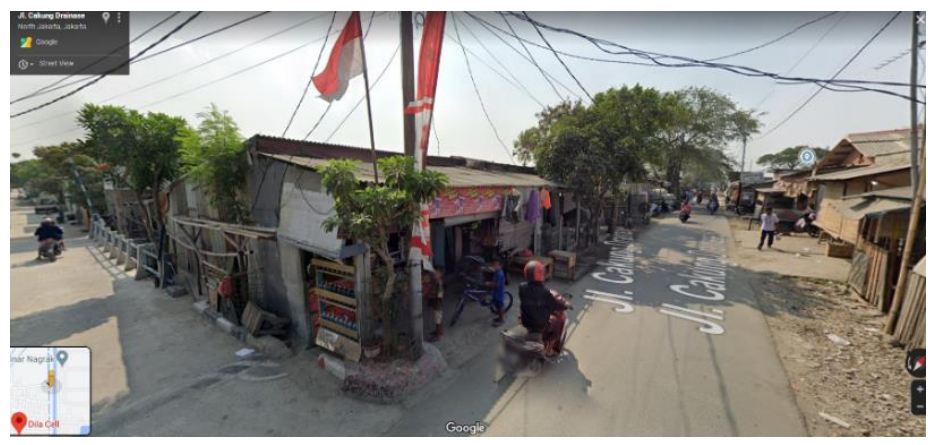

Gambar 1. Eksisting Kampung Sawah

Sumber: Google Maps, 2021

Aktivitas utama penduduk Kampung Sawah selain berhuni ialah berdagang. Selain bekerja sebagai buruh/karyawan, sebagian penduduk ada yang berjualan di depan rumah seperti membuka warung atau rumah makan, serta terdapat bisnis PKL gerobak di pinggir jalan. Lahan yang dijadikan warung ini juga dimanfaatkan warga sebagai ruang kumpul komunal orang tua maupun anak-anak, dikarenakan minimnya ruang sosial oleh keterbatasan lahan. Keterbatasan lahan ini menyebabkan warga terbiasa untuk berbagi ruang publik sehingga kehidupan penduduk di gang menjadi lebih erat dibandingkan penduduk perkotaan. Letak ruang komunal ini ada di depan rumah penduduk yang langsung berbatasan dengan jalan umum yang cukup sempit $( \pm 6 \mathrm{~m})$ menyebabkan kurangnya keamanan terutama bagi anak-anak. Terutama di Kampung Sawah terdapat banyak gang dan memiliki aktivitas yang padat di dalamnya, semakin membahayakan dan mengganggu lalu lintas.

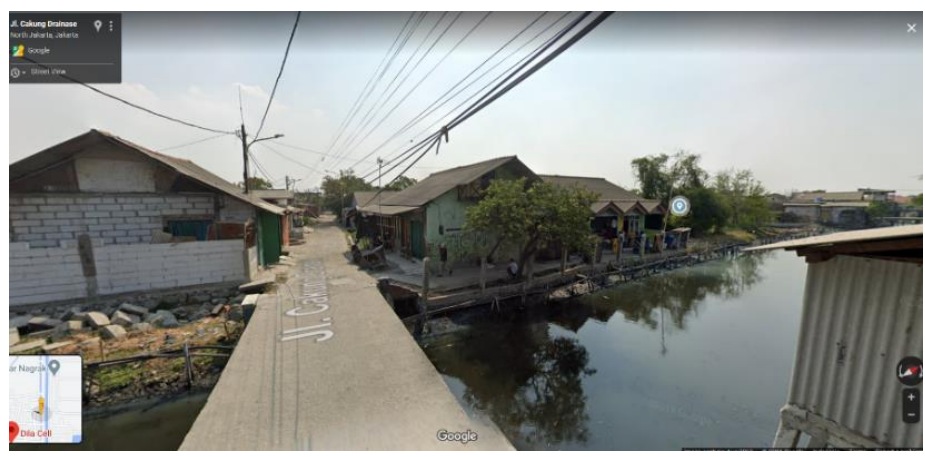

Gambar 2. Eksisting Akses Masuk Kampung Sawah

Sumber: Google Maps, 2021

\section{Penduduk Eksisting Kampung Sawah}

Penduduk Kampung Sawah memiliki warga lokal yang mayoritas sudah tinggal di area tersebut sejak dulu, dan memiliki identitas sebagai warga Jakarta. Sedangkan sebagian kecil lagi penduduk yang baru menetap karena lokasi ini lebih dekat ke tempat kerja (buruh/karyawan pabrik). Housing ini diharapkan mampu menampung penduduk baru maupun lama yang terus berkembang turun temurun dan memerlukan hunian baru yang dekat dengan tempat kerja.

\section{Kebutuhan Energi Listrik}

Sebagai area permukiman bagi pekerja buruh/karyawan, kebutuhan energi untuk berhuni terutama air dan listrik tentunya semakin meningkat dan bervariasi. Kegiatan warga yang di pagisiang hari terjadi di tempat kerja, sedangkan di sore-malam hari para pekerja kembali ke rumah dan kebutuhan energi di rentang waktu itu sangat tinggi, menyebabkan rawannya kekurangan pasokan energi di waktu yang sama. Sumber energi listrik saat ini hanyalah dari PDAM yang seringkali tidak stabil di area ini. Oleh karena itu dilakukan pemanfaatan solar panel untuk memberi cadangan listrik terutama di malam hari, agar menjadi lebih stabil. 


\section{Strategi Desain Compact \& Sustainable}

Pola sirkulasi, aksesibilitas, zoning aktivitas, serta fungsi hybrid komunal dan komersil menjadi fokus rancangan.

Akses Hunian Compact $><$ Pemukiman Eksisting Kampung Sawah

Untuk hunian yang berkesinambungan dengan sekitar tapak, maka akses dibuat lebih banyak. Terdapat 2 akses utama dari timur(Gg. Lovebird) dan barat(Jl. Komp. PT. Puninar) serta 2 akses minor dari selatan dan utara(Jl. Cakung Drainase). Akses kendaraan memutari kompleks hunian dengan mempertahankan jalan lokal eksisting. Sedangkan dalam kompleks hunian diutamakan hanya untuk pejalan kaki.

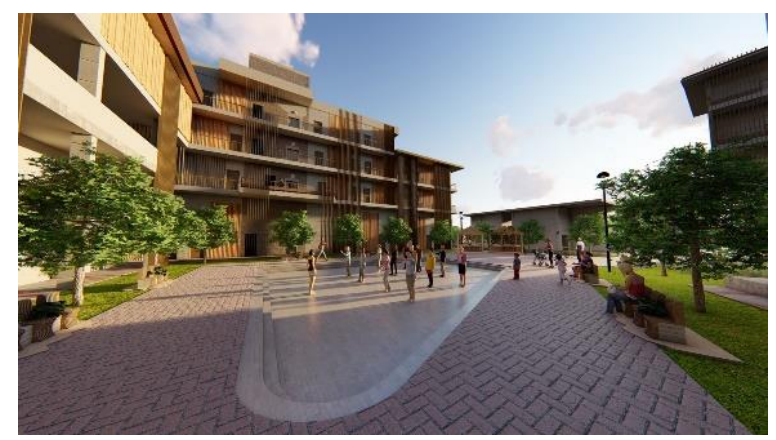

Gambar 3. Courtyard khusus pedestrian

Sumber: Penulis, 2021

Kota dalam Kota

Kehidupan di dalam hunian ini mampu mencakup seluruh kebutuhan kehidupan masyarakat, sehingga penduduk dapat hidup independen di dalamnya, tetapi sekaligus terhubung dengan fasilitas di luar hunian yang juga mendukung penduduk lokal. Contohnya seperti fasilitas ibadah mushola yang terletak kurang 50m dari lokasi hunian compact, sehingga hunian tidak lagi perlu menyediakan fasilitas tersebut melainkan memberi akses langsung ke sana. Hal ini menunjukkan juga poin aksesibilitas dalam dan ke luar hunian. Area entrance utama berupa komersil dan komunal area. Area komersil ini berupa booth atau pertokoan formal. Sedangkan di sepanjang jalan lingkungan menuju entrance terdapat area komersil informal, di mana disediakan booth tidak permanen untuk PKL yang dapat diakses langsung tanpa masuk ke dalam area hunian. Area ini dilalui oleh overpass bridge di atasnya.

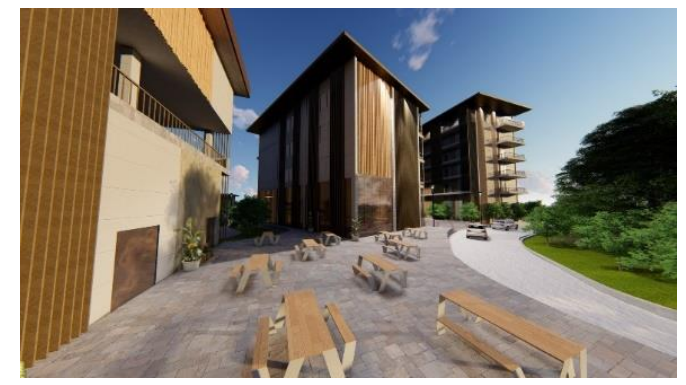

Gambar 4. Hybrid Komersil dan Komunal Area

Sumber: Penulis, 2021

Ruang Publik = Ruang Teknis $=$ Komersil

Massa kompleks disusun membentuk courtyard/ lapangan umum sebagai ruang publik serbaguna, khusus untuk pejalan kaki. Courtyard ini tetap terhubung ke akses keluar-masuk hunian ke jalan raya. Ruang publik juga memanfaatkan selasar unit atau sepanjang lorong unit hunian untuk memaksimalkan penggunaan ruang. 


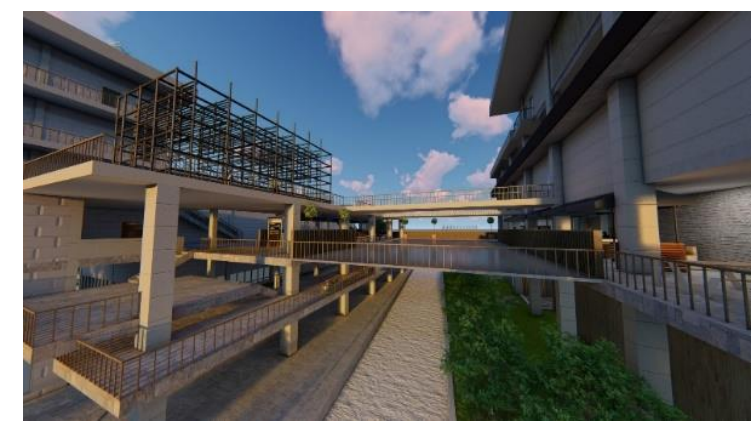

Gambar 5. Overpass Bridge

Sumber: Penulis, 2021

Strategi lain pemanfaatan ruang publik ialah memadukan fungsi teknis pengolahan energi solar panel dengan ruang komunal. Karena fungsi teknis berupa kantor dan laboratorium yang biasanya tertutup justru dijadikan area semi publik yang di mana warga dan pengunjung dapat melihat proses di dalamnya. Selain sebagai area atraksi bagi pengunjung, hal ini juga dapat memberi kesadaran akan kehidupan warga yang ramah lingkungan dan hemat energi. Hal ini terlihat di overpass bridge dengan memberi dinding kaca di area olah energi dan lab, yang bisa dilihat langsung dari overpass bridge sebagai area komunal dan komersil.

\section{Biaya Minimal}

Baik biaya pembangunan maupun biaya pemeliharaan untuk kehidupan warga, ditujukan memiliki biaya serendah mungkin namun tetap berkualitas.

\section{Rancangan Unit, Fasad dan Utilitas}

Sistem struktur menggunakan modul $6 \times 8$ yang menyesuaikan dengan tipe unit kamar sebesar $48 \mathrm{~m} 2$ (1/2 kamar) dan 60m2 (2 kamar). Jumlah unit diambil dari 10\% jumlah kepala keluarga di Kampung Sawah saat ini, serta maksimal luas KDB yang dapat digunakan. Total unit sebanyak 128 unit dengan 120 buah tipe $48 \mathrm{~m} 2$ dan 8 buah tipe $60 \mathrm{~m} 2$. Unit hunian $48 \mathrm{~m} 2$ dan $60 \mathrm{~m} 2$ untuk keluarga beranggotakan 4-6 orang.

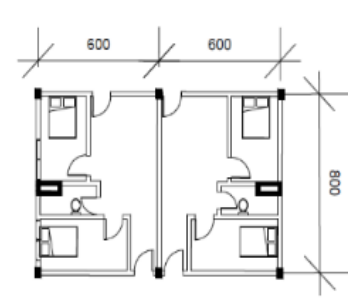

(1) DENAH UNIT 48M2

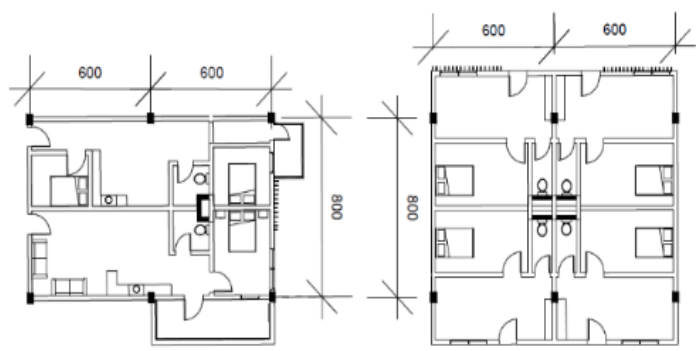

(2) DENAH UNIT 6OM2

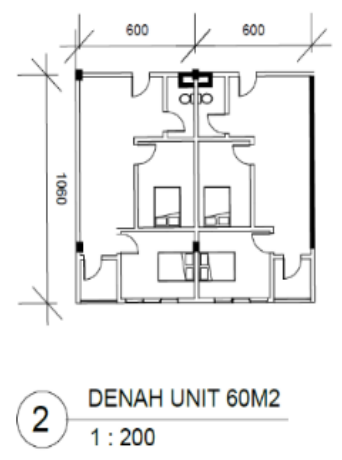

Gambar 6. Unit Hunian

Sumber: Penulis, 2021

Sistem utilitas berbentuk shaft terbagi menjadi 2 pusat, satu di area kompleks tower huni dan satu di tower pengolahan energi. Penggunaan solar panel di tower pengolahan energi dapat memenuhi sekitar hingga 20\% kebutuhan listrik tiap unit. Sistem solar panel berupa shaft dimiliki setiap tower dengan pusat pengolahan di satu tower, untuk kemudian didistribusikan kembali melalui tanah ke seluruh tower huni. 


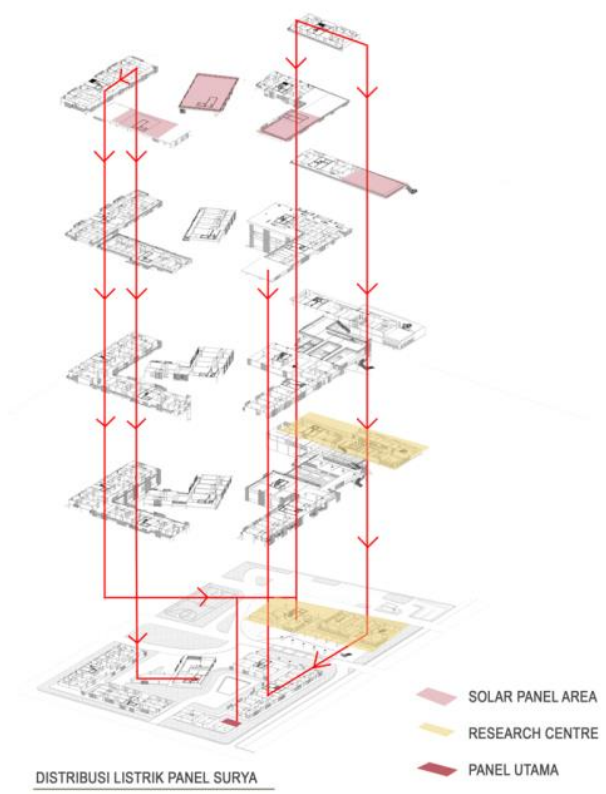

Gambar 7. Distribusi Listrik Panel Surya

Sumber: Penulis, 2021

Penggunaan material utama struktur ialah balok beton, yang juga digunakan pada fasade. Kombinasi material bambu dengan beton juga dilakukan dan diaplikasikan di fasade eksterior bangunan untuk aspek lebih organik. Perpaduan material ini untuk menonjolkan kembali kesan 'kampung kota' di Kampung Sawah.

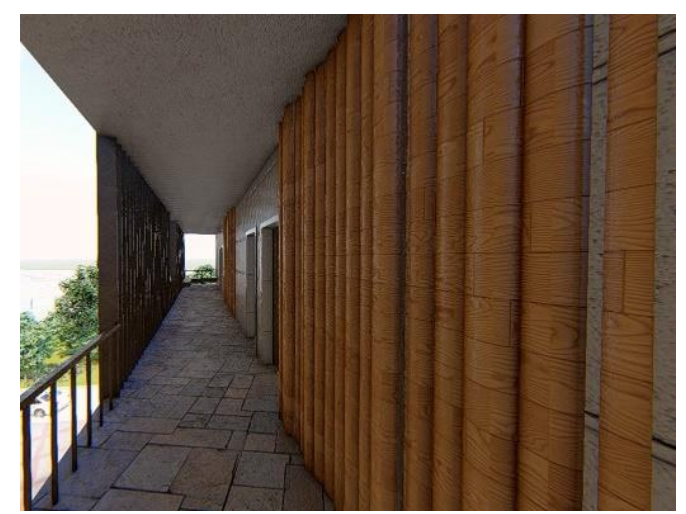

Gambar 8. Fasade Bambu + Beton sebagai Partisi Unit Sumber: Penulis, 2021

\section{Zoning}

Massa dibagi menjadi 3 tower: Tower Alpha, Beta, Gamma. Setiap tower terdapat hunian dengan area solar panel di setiap rooftop tower. Massa disusun sehingga memiliki courtyard di area tengah sebagai ruang komunal. Terdapat overpass bridge di atas jalan lingkungan menuju entrance yang menghubungkan housing ke area pengolahan energi di tower Gamma. Sedangkan transportasi bangunan vertikal berupa elevator dan tangga. 

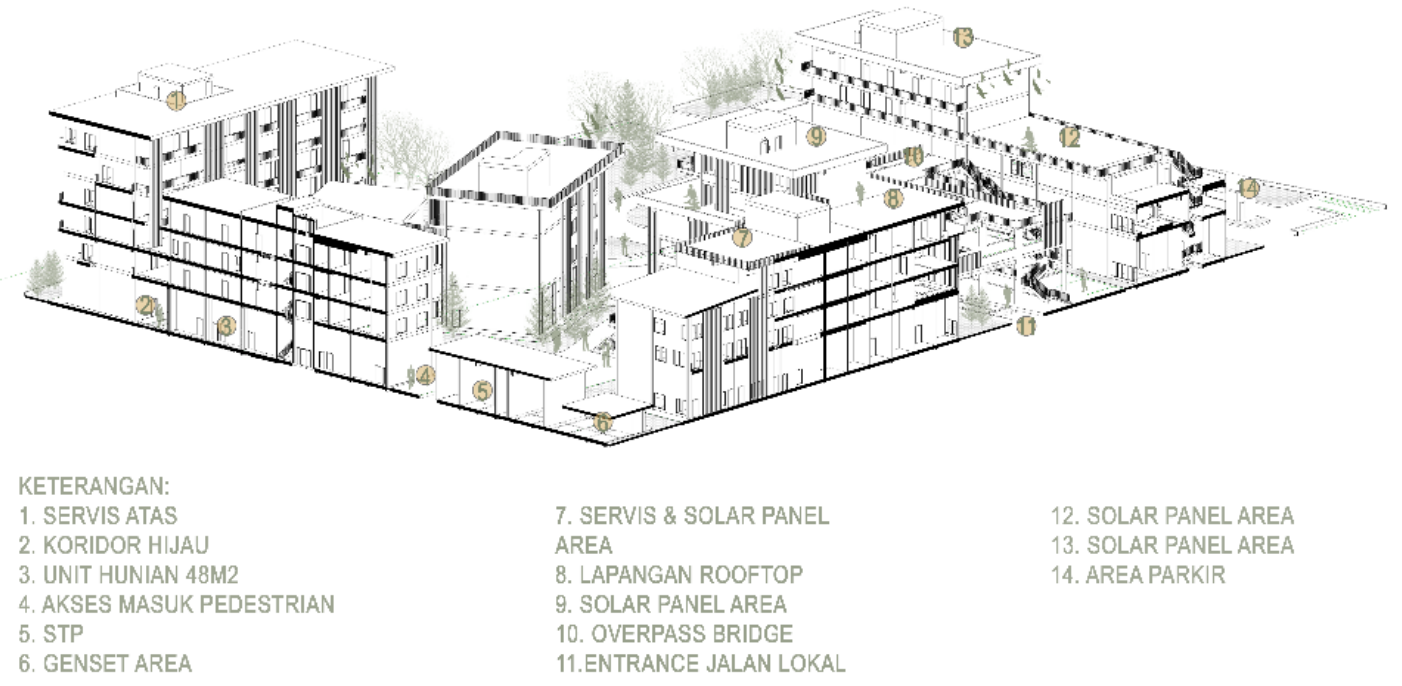

7. SERVIS \& SOLAR PANEL AREA

8. LAPANGAN ROOFTOP

9. SOLAR PANEL AREA

10. OVERPASS BRIDGE

11.ENTRANCE JALAN LOKAL
12. SOLAR PANEL AREA

13. SOLAR PANEL AREA

14. AREA PARKIR

\section{POTONGAN PERSPEKTIF}

Gambar 9. Zoning

Sumber: Penulis, 2021

Dengan KDB 40\% dan jumlah lantai antara 4-6 lantai, lantai dasar sebagian besar merupakan area publik dan area komunal utama terutama di area dekat entrance dan lapangan serba guna. Terdapat unit rumah di lantai dasar yang langsung menghadap lapangan, namun tetap dipisahkan oleh area hijau. Lantai dasar dinaikkan sekitar 1m dari jalan lokal sebagai tanggapan ancaman banjir jika Kali RW Malang meluap.

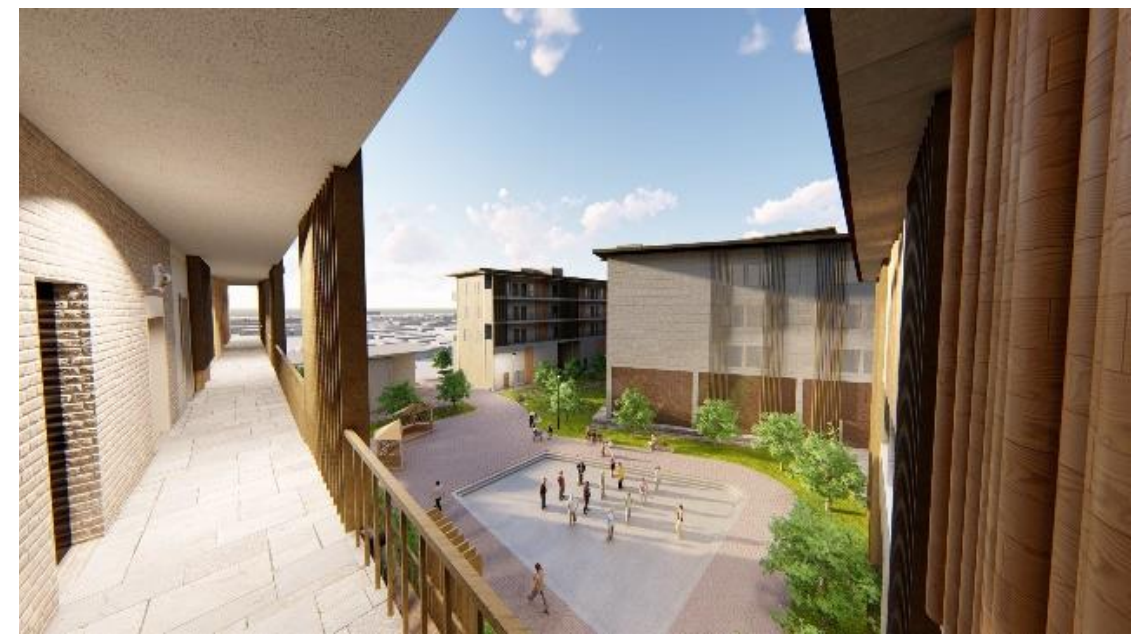

Gambar 10. Koridor Hunian

Sumber: Penulis, 2021

Dari lantai 2 hingga 6 merupakan unit rumah bersifat privasi. Sedangkan rooftop merupakan area yang hanya dapat diakses oleh penghuni karena berupa lapangan olahraga dan area solar panel serta utilitas yang bersifat teknis dan khusus untuk karyawan. Massa tower dibuat ramping untuk penerimaan cahaya maksimal serta jalur pergantian udara, sehingga udara dapat masuk ke unit rumah-rumah. Unit rumah dibuat single loaded dengan koridor terbuka untuk sirkulasi udara, serta area duduk komunal di sepanjang koridor setiap beberapa unit. Desain koridor balkon dapat mendukung ruang sosial dan mengurangi sekat antar warga penghuni kompleks yang mempererat hubungan satu sama lain. 


\section{KESIMPULAN}

\section{Kesimpulan}

Cara membentuk kawasan kampung kota yang berintegrasi dengan menerapkan prinsip compact city dapat dicapai dengan menentukan program hunian sustainable. Hal ini diwujudkan dengan menerapkan sistem pengolahan energi untuk menekan biaya pemeliharaan dan kebutuhan energi, pemudahan aksesibilitas ke hunian yang tetap kontekstual dengan kondisi eksisting, prinsip kota dalam kota, serta fungsi hybrid. Fungsi hybrid komersil merupakan bentuk kegiatan penduduk lokal kampung kota yang sudah ada dan dipertahankan. Hybrid dalam proyek ini dicapai dengan memadukan fungsi komersil, publik/komunal dengan fungsi teknis, menjadi tak bersekat namun tetap memiliki zonasi masing-masing untuk menjalankan aktivitas di dalamnya secara maksimal. Penyediaan ruang-ruang publik mampu mewadahi kegiatan ekonomi masyarakat setempat dan mendukung perekonomian usaha mikro. Sedangkan ruang teknis yang lebih diekspos dapat memberikan kesadaran warga lokal akan kehidupan hemat energi sekaligus menjawab permasalahan kebutuhan hunian yang disebabkan urban sprawl di perkotaan.

\section{Saran}

Diharapkan dapat dilakukan studi lebih lanjut mengenai keberadaan Kampung Kota saat ini yang jika dimanfaatkan dapat menjadi solusi permukiman kota mengkini, tanggap permasalahan urban sprawl dan kebutuhan energi, terutama dapat sekaligus mendukung program penataan permukiman kumuh.

\section{REFERENSI}

Begon, M., Harper, J.L., Townsend, C.R. (1986). Ecology. Individuals, Populations and Communities. Blackwell Sci. Pub. Oxford.

Budiharjo, E. (1992). Sejumlah Masalah Perkampungan Kota. Bandung: Alumni. BPS Jakarta Utara. (2019). Kecamatan Cilincing dalam Angka 2019. Jakarta: BPS.

Cahyo N., A. (2009). Kampung Kota Sebagai Sebuah Titik Tolak Dalam Membentuk Urbanitas Dan Ruang Kota Berkelanjutan. Bandar Lampung.

Frick, H. (2007). Dasar-Dasar Arsitektur Ekologis. Yogyakarta: Kanisius.

Gunawan, B., dkk. (2012). Buku Pedoman Energi Efisiensi untuk Desain Bangunan Gedung di Indonesia. Jakarta: Energy Efficiency and Conservation Clearing House Indonesia.

Magdalena, E. D., dkk. (2016). Implementasi Konsep Zero Energy Building (ZEB) dari Pendekatan Eco-Friendly Pada Rancangan Arsitektur.

Sihombing, A. (2004). The Transformation of Kampung Kota: Symbiosys Between Kampung And Kota, A Case Study from Jakarta. Jakarta.

The National Institute of Building Sciences. (2015). Energy Efficiency \& Renewable Energy / A Common Definition for Zero Energy Buildings. USA: US Department of Energy. 